\title{
Abuse in the church? A social constructionist challenge to pastoral ministry
}

\begin{tabular}{|c|c|}
\hline \multicolumn{2}{|c|}{$\begin{array}{l}\text { Authors: } \\
\text { Rosemaré A. Visser }^{1} \\
\text { Yolanda Dreyer }^{1}\end{array}$} \\
\hline $\begin{array}{l}\text { Affiliations: } \\
{ }^{1} \text { Department } \\
\text { Theology, Uni } \\
\text { Pretoria, Sout }\end{array}$ & $\begin{array}{l}\text { of Practical } \\
\text { versity of } \\
\text { h Africa }\end{array}$ \\
\hline $\begin{array}{l}\text { Note: } \\
\text { This article re } \\
\text { reworked vers } \\
\text { from the PhD } \\
\text { (University of } \\
\text { April 2013), er } \\
\text { in the church: } \\
\text { and challenge } \\
\text { ministry', with } \\
\text { Yolanda Dreye }\end{array}$ & $\begin{array}{l}\text { presents a } \\
\text { sion of aspects } \\
\text { dissertation } \\
\text { Pretoria, } \\
\text { ntitled 'Abuse } \\
\text { An appeal } \\
\text { to pastoral } \\
\text { Prof. Dr } \\
\text { er as supervisor. }\end{array}$ \\
\hline $\begin{array}{l}\text { Corresponder } \\
\text { Rosemaré Viss }\end{array}$ & $\begin{array}{l}\text { nce to: } \\
\text { ser }\end{array}$ \\
\hline $\begin{array}{l}\text { Email: } \\
\text { rosemare.ann } \\
\text { com }\end{array}$ & .visser@gmail. \\
\hline $\begin{array}{l}\text { Postal addres } \\
\text { PO Box } 33573 \\
0102 \text {, South A }\end{array}$ & $\begin{array}{l}\text { s: } \\
\text { 3, Menlo Park } \\
\text { frica }\end{array}$ \\
\hline $\begin{array}{l}\text { Dates: } \\
\text { Received: } 07 \\
\text { Accepted: } 27 \\
\text { Published: } 11\end{array}$ & $\begin{array}{l} \\
\text { Eeb. } 2013 \\
\text { Apr. } 2013 \\
\text { July } 2013\end{array}$ \\
\hline $\begin{array}{l}\text { How to cite th } \\
\text { Visser, R.A. \& } \\
\text { 2013, 'Abuse i } \\
\text { A social const } \\
\text { challenge to p } \\
\text { ministry', HTS } \\
\text { Studies/Theol } \\
69(1), \text { Art. \#19 } \\
\text { http://dx.doi. } \\
\text { hts.v69i1.193 }\end{array}$ & $\begin{array}{l}\text { is article: } \\
\text { Dreyer, Y., } \\
\text { n the church? } \\
\text { ructionist } \\
\text { astoral } \\
\text { Teologiese } \\
\text { ogical Studies } \\
39,13 \text { pages. } \\
\text { org/10.4102/ } \\
\end{array}$ \\
\hline $\begin{array}{l}\text { Copyright: } \\
\text { C 2013. The A } \\
\text { Licensee: AOS } \\
\text { OpenJournals } \\
\text { is licensed unc } \\
\text { Creative Comr } \\
\text { Attribution Lic }\end{array}$ & $\begin{array}{l}\text { Authors. } \\
\text { IS } \\
\text { This work } \\
\text { der the } \\
\text { nons } \\
\text { ense. }\end{array}$ \\
\hline 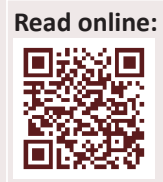 & $\begin{array}{l}\text { Scan this QR } \\
\text { code with your } \\
\text { smart phone or } \\
\text { mobile device } \\
\text { to read online. }\end{array}$ \\
\hline
\end{tabular}

The article focuses on abusive practices in the faith community. It indicates that abusive behaviour is more often than not unintentional and is ostensibly driven by a zeal for God and the church. The article explores this anomaly by examining the phenomenon of abuse in the faith community from a social constructionist, psychological, sociological and theological perspective. Pastoral ministry is challenged to foster self-reflexivity and awareness, as well as to revisit current (outdated) beliefs and practices, to test their suitability for the postmodern context in which the church is to tell and live her story.

\section{Introduction}

This article investigates abusive practices in the church and the possibility that these practices are based on social constructions of the world, religion, Scripture, and church life and action in general. The argument put forth is that practices and experiences of abuse are often rooted in socially constructed 'absolute truths' which people stubbornly hold with regard to the world, religion and church. In the postmodern paradigm these 'absolute truths' are described as traditionally, historically and culturally shaped dominant discourses or, in the Christian story, grand or dominant narratives.

Critical theological reflection and a willingness and openness to dialogue, challenge and, if needed, changed or altered ways of seeing and doing are encouraged. Similarly, self-reflexivity and a deconstruction and reconstruction of current selves, community and practice are promoted and encouraged. Such an extensive reflection on social constructionism leaves one with a feeling that the one issue that seems to dominate the discussions has to do with reality or the way things are. What is reality? Is there an objective reality that can be accepted as final objective truth? How do we go about this? How do we do theology in and around this?

The psychological theorization of Kelly (1955) and Gergen (2009) show how social constructivist and social constructionist theorization explain certain dynamics in social structures. Sociological theories of Berger and Luckmann $(1966,1967)$ demonstrate how human beings solidify their own social constructions to become 'reality'. This article utilises all of the above theories in order to explain the interaction between the individual and the environment. From a theological perspective the teachings of Jesus and Paul in the New Testament are explored.

The investigation is thus from three perspectives, namely a psychological, sociological and theological perspective.

\section{A psychological perspective}

Psychology is the discipline of studying attitudes and attributions and how they are formed, firstly concerning itself with 'both the cognitive (intellectual) and affective (emotional) sides of a person, as well as the behaviour that results from and is influenced by thoughts and emotions' (Sternberg 2001:423). Butler (2012) offers a definition that fits in a postmodern, social constructionist, narrative frame:

\footnotetext{
... psychology theory is a construct that attempts to explain observed complex behaviours, which have their origin in consciousness or unconsciousness, and are interpreted through the features of the culture and experiences of the observer. (p. 102)
}

Butler's definition presupposes the interaction between the individual and the environment as well as subjectivity of the observer. Gergen (2009:1-12) describes social constructionist psychology as placing beliefs, understanding and emotions in the context of relationships in the form of stories, made up of discourses about everything we encounter. These are developed in relationship with others in the world and should be understood in relation to relationship and social environment (cf. Gergen 1985:266). George Kelly (1955; cf. Maddi 1996:174ff.) was the first to explain this interaction between individual and environment with his personal construct 
theory and metaphoric reference to the individual as scientist, developing personal constructs on a cognitive and biological level through the nervous system in order to make sense of and test experience and reality. Social constructivism is psychological theorization about how certain social phenomena develop in humans in social contexts. For the purposes of this article the social phenomena are abusive actions and behaviour, and the social context is the church.

Chiari and Nuzzo (1996:163-184, 2004) distinguish between two broad categories of constructivism: 'epistemological' and 'hermeneutic'. 'Epistemological' constructivism holds that many, equally legitimate constructions of the same external reality can exist, whilst hermeneutic constructivism views knowledge as 'interpretation'. Hermeneutic constructivism deems such interpretations to be historically as well as culturally and contextually verifiable, in contrast with timeless, universally valid absolutes. These interpretations are formed linguistically and are negotiated within social contexts rather than products of cognition or of any one individual.

Chiari and Nuzzo (2004) note that, although the majority constructivists acknowledge the existence of a 'real world' outside of human consciousness, their interest lies in the nuances in people's construction of the world than in evaluatiing the extent to which such constructions are 'true in representing such presumed external reality.

Freedman and Combs (1996) refer to psychologist Gregory Bateson's (1972) 'map' metaphor which suggests that:

... all our knowledge of the world is carried in the form of various mental maps of 'external' and 'objective' reality, and that different maps lead to different interpretations of 'reality'. (p. 15)

What is objective or absolute is undeniably experienced, thought about and acted upon in different and unique ways, and also affected by people's genetically inherited qualities. Social constructivism should not be confused with constructionist theory. Goldenberg and Goldenberg (2008) distinguish constructivism from constructionism. They put it as follows:

Both address the nature of knowing and reject the idea of describing an objective reality. Constructivism, however, is rooted in the biology of cognition - more specifically ... each person's perceptions are filtered throughout individual nervous systems. Each of us brings different assumptions to the same situation - we construe reality differently - as a result of our own mental and symbolic processes and meaning-making structure. (p. 342)

Social constructionism assumes that no one sees an objective reality, but that it expands on the social constructivist view by '... asserting that what we do construct from what we observe arises from the language system, relationships, and culture we share with others' (Goldenberg \& Goldenberg 2008:342). Our attitudes, beliefs, memories, and emotional reactions arise out of relational experiences.

Kelly's constructivist theory demonstrates that the act of construing our own reality and meaning originates on a deep personal (even biological) level and not merely on a social level. Kelly's constructivist cognitive dissonance personality theory is known for his emphasis on how people create their own lives through construing experience (interpretation), by forming their own constructs based on experiences, for example religious/non-religious, right/wrong, Godly/ ungodly. This article is about such social constructions of people and groups and how they affect relationships in the church - often in destructive ways. Kelly proposes that this construction process, although social, happens on a cognitive level via the nervous system (Freedman \& Combs 1996:26; cf. Hoffman 1990:2; Goldenberg \& Goldenberg 2008:342).

Although Kelly focuses attention on cognitive construing, surely it cannot be denied that relationships and social context play a role in the process, as asserted by social constructionist thought. Kelly distinguishes between permeable and preemptive constructs. If a person's construct is permeable, new experiences and encounters can be subsumed by it (Kelly 1955:64-68). If it is pre-emptive, it is closed to new ideas and experiences. This depends on the flexibility and adaptability of the individual. People use their existing construct system to predict and control their environment. If pain is experienced by a perceived discrepancy, the individual takes action to alleviate the discomfort (Maddi 1996:174-186). Kelly implies that perception of reality has to do with the meaning a person attaches to it. It implies a freedom of choice to change, adapt, or reject any held meaning which does not work for the individual's happiness and comfort. Kelly himself termed his approach 'alternative constructivism', which means that a person can construct mentally alternative meaning/s to any idea, event, and experience in the present, past or future. Kelly's (1955) personal construct psychology assumes the following:

- Individuals are the creators of their own ways of seeing and perceiving their experiential world.

- Constructs are construed by humans and tested for workability.

- Constructs are organised and categorised into mental systems, which make up groups of constructs into subordinate and super-ordinate relationships.

- Similar events or experiences can belong to two or more mental systems, whilst they do not belong to any system.

- People's practical systems are specifically focused and are limited in ranges of convenience.

According to Kelly (1955:14; cf. Chiari \& Nuzzo 1996:163-184), constructs are like transparent patterns or templates which function to test reality for a suitable fit, construct reality and make predictions. The success of the fits, constructions and predictions determines whether constructs, and eventually whole construct systems, are accepted, revised or even recreated (Smith 2008:15). Kelly (1955; cf. Smith 2008:15-16) distinguishes between different realities by the following distinctions:

- Individuality: The differences in people's constructions of experiences and events.

- Communality: The communal constructions of people, whereby similar psychological processes are taking 
place and employed by different persons of the same community.

- Sociality: The extent to which one person construes the construction processes of another. Such an individual may play a role in a social process involving the other person.

According to Neimeyer and Bridges (2004), Kelly accentuates that individuality and communality need to be considered together for developing an understanding of people's psychological processes (cf. Smith 2008:15).

This is done by looking for similarities to group together, but also by contrasting them, in other words, by differentiating them from what they are not. For example, rigidity can only be understood in the light of its contrast, flexibility. These constructions form a basis for individuality (self-definition) and communality (social interaction). Neimeyer and Bridges (2004) write about Kelly's 'core constructs', that they are often 'unverbalizable' meanings. They are central in the shaping and organising of our complete construct systems. They ultimately represent our most basic values and sense of self. Core constructs are often private idiosyncratic meanings passed on and given validation as 'truth' within relationship and in social context (Smith 2008:15-16). Bugental (1976:283), a student of Kelly, recalls how Kelly very casually stated: 'The key to man's destiny is his ability to reinterpret what he cannot deny.'

Different from other cognitive psychological theory, there is greater and stronger emphasis in Kelly's theory on emotional experiences, which function as indicators of possible or real challenge or change of existing deep-seated constructs of one's existing predicted or expected reality. Threat and anxiety may be experienced when encountering ideas, views, events or anything that may seem unfamiliar, strange and/ or disconnected from currently held construct systems. This strong link between emotion and constructed meaning makes Kelly's 'Personal Construct Theory' very suitable for the reflection offered in this article, and for anyone concerned with issues such as '... relational breakdown, trauma, and loss, all of which can fundamentally undercut one's assumptive world, triggering a host of significant emotional and behavioural responses' (Neimeyer \& Bridges 2004).

Neimeyer and Bridges (2004) highlight the way in which personal identity is constructed and transformed in a social context, focusing on the role of language in defining reality. They go on to stress that the role of the counsellor attempting to assist clients with problems of living is to focus on the created meaning of the counsellee as expressed in language. This is in agreement with postmodernism as well as with other constructivist, social constructionist as well as narrative approaches. According to Kelly's theory, language seems to play a secondary role to the cognitive construing process. Nevertheless, language plays a crucial role in the therapeutic setting (Neimeyer \& Bridges 2004).

Smith (2008:15) concurs by connecting Kelly's constructivist theory with social constructionist theory: 'The "fundamental postulate" of Kelly's theory of personal constructs expresses the constructionist outlook strongly - a person's processes are psychologically channelized by the way he anticipates events.' Smith (2008:15), however, adds that Kelly wants the person to be seen as an active scientist testing and making changes to constructs as the need arises. This is different from Gergen's social constructionist theory as I explain in later paragraphs.

Kelly's theory offers an explanation for the constructs which may be held in the church, the anxieties which may be underlying some of the abusive actions when individuals encounter and/or are confronted with alien constructs. Further, it may explain why some are silent about abuse, possibly because of communality: they share constructs with others who, possibly unintentionally and unaware, treat them (and others) in ways which may be experienced as abuse. It also explains the dynamics between those whose constructs make up what social constructionist thought refers to as dominant discourse and narrative, and others who hold alternative constructs, discourses and narratives.

Gergen (2009) in the preface to his monograph An invitation to social construction comments about social constructionism (which he says some narrowly refer to as constructivism; hence also the inclusion of constructivist theory above) that one of its most important features is its relevance to the times and its focus on practice.

According to Gergen (2009:2), what we accept as 'the world' depends significantly on 'how we approach it', which in turn again depends on the social relationships of which we form part. Social constructionism then, says Gergen (ibid), challenges '... long honoured words like "truth", "objectivity", "reason" and "knowledge", when grasped completely ...' and self-understanding, including thoughts, emotions and desires, will be altered and transformed. Everything will come to have entirely new meaning and to be seen in a different light, including world conflict:

... social constructionist ideas emerge from a process of dialogue, a dialogue that is ongoing, and to which anyone - even you as reader - may contribute. As a result, however, there is no one, authoritative account that represents all the participants ... [but] many different views, and some tensions among them. (ibid)

This describes constructionism and the intentions with this article: an appeal for ongoing dialogue, a challenging of truths and objectivity, and that long-honoured ideas, self and relationships will take on an entirely new level of meaning. This article forms part of the process of ongoing dialogue, stimulating further ideas.

A brief summary of the basic social constructionist assumptions as described by Gergen (2009:5-13) - with a fundamental vision in mind - follows:

As we speak together, listen to new voices, raise questions, ponder alternatives, and play at the edges of common sense, we cross the threshold into new worlds of meaning. The future is ours - together - to create. (ibid:5)

Different ways of describing, using language and talking, are possible to describe 'what there is' (Gergen 2009:5). So, 
for example, an understanding of Hitler's cause does not depend on the happenings: different language was and is used to describe the events around the Holocaust, for example. Another example: the events in South Africa during apartheid and even now after the liberation from it, do not dictate how conservative thinkers use language to describe it. The 'New South Africa' and the 'Rainbow Nation' are both new constructs to many South Africans. Some, however, who appreciate the 'New South Africa' and the 'Rainbow Nation', tested, challenged and reinterpreted old constructs, fitting to Kelly's constructivist paradigm. These new terms, in the light of what Gergen says above, are after all only a reflection of people's experiences with regard to changes in the context. In the church, once there is awareness about different ways of describing, it could contribute to greater tolerance and fewer experiences of abuse.

This does not mean that social constructionism denies the reality 'out there'. It simply means different 'realities' or 'what there is' exist as constructed in different approaches, cultural thought and experience and relationships. In the church, for example, some may describe the same sermon, depending on tradition and social experience, as liberating, whilst at the same time, for others, it may be constricting.

Social constructionism, according to Gergen (2009:5-8), further assumes that the way the world is understood is achieved in relationship. People negotiate, agree, compare views and agree about what constitutes 'the world'. Relationship thus takes precedence over anything we perceive as logical and understandable in our reality. Before relationships, there is therefore no existence, objects, people - reality. 'This suggests that any words, phrases or sentences that are perfectly sensible to us now could, under certain conditions of relationship, be reduced to nonsense' (ibid:8). Gergen (ibid) illustrates this by discussing his desk as described by the scientist, physicist, psychologist, and how any one of us can be described differently by people from different professions.

In every social structure or 'entity', such as a church or a tennis game, patterns of coordination (agreed upon in member relationships) which are fairly reliable (contextspecific) are developed. These serve certain functions in the specific context. Gergen (2009:9) refers to Wittgenstein's description of these actions, words, and objects belonging to a certain context as a 'form of life'. Gergen (ibid) asserts:

When we say that a certain description is 'accurate' ... or 'true' we are not judging it according to how well it pictures the world. Rather, we are saying that the words have come to function as 'truth telling' within the rules of a particular game ... or ... according to certain conventions of certain groups ... successful functioning within the relational ritual ... became truth telling. (ibid:10)

It is no intellectual challenge to figure out how abusive relationships can occur if there is no awareness of this principle. This can also provide answers to the silence of many: it could simply be acceptable to 'abuse' someone who thinks and behaves outside these rules and patterns.
Gergen mentions the danger of loss of what is possessed real or tradition - if we deconstruct any of these as not being 'absolute truth', or abandon forms of life by abandoning languages of what is real and good, Gergen continues (after referring by way of example to churches dying and emptied, becoming community centres, as certain concepts are no longer agreed upon and accepted in a different context): 'Sustaining one's traditions requires a continuous process of regenerating meaning together' (2009:11). Gergen invites 'generative discourses ... ways of talking and writing or representing (as in photography, film, art, theatre, and the like) that simultaneously challenge existing traditions of understanding, and offer new possibilities for action' (ibid:12).

Social constructionism and also this article, do not argue for a rejection of tradition, but simply for what Gergen terms 'generative discourses': a revisiting of traditions, patterns of belief and activity, which may clash with new postmodern, and now post-postmodern times, although they may have been perfectly suitable some time ago.

Constructionists, according to Gergen (2009), should celebrate 'critical reflexivity', which he describes as:
... the attempt to place one's premises into question, to suspend the 'obvious', to listen to alternative framings of reality, and to grapple with the comparative outcomes of multiple standpoints $\ldots$ an unrelenting concern with the blinding potential of the 'taken-for-granted'. If we are to build together toward a more viable future then we must be prepared to doubt everything we have accepted as real, true, right, necessary or essential. (p. 13)

For those readers who at this point might be concerned about a rejection of major traditions, Gergen (2005:13) concludes that critical reflection as described above is not '... necessarily a prelude to rejecting our major traditions.' It simply implies the recognition of these as historically and culturally situated traditions. It also implies the recognition that other traditions may be equally legitimate and valid within their own contexts. It finally acts as invitation to '... the kind of dialogue that might lead to common ground.'

This article is also about this type of critical reflection - critically reflecting on what some experienced and constructed as abuse in relationship through the use of language, as well as critically reflecting on what some call 'true', 'right', 'just', and so on, justifying actions that drive others away from the church.

Kelly's theory, as discussed earlier in this article, with its strong emphasis on affect and constructed meaning, serves to explain the emotionally-driven abusive discourses in structures such as the church. Similarly, Gergen's social constructionist thought outlined in the previous paragraphs creates awareness and demonstrates that what we often perceive as truth, reality, objective and 'out there' only to be studied, learned and applied to our lives, was constructed (shaped, built, formed) by humans in relationship agreeing, by negotiation, talk, and using language, finding their expression in dominant narratives (stories), made up of dominant discourses. 
Human individual behaviour extends beyond the individual's inner person, processes and functioning, but is driven by and founded on beliefs about what is real, true, good, and so forth. Language is instrumental in representing constructed realities and worlds, and these constructions are not necessarily true representations or dependent on what is out there, which we would usually term objective matter, reality or truth.

The above serves to emphasise and encourage re-evaluation and critical reflection on those things, truths, ideas, beliefs and whatever else we want to describe that we disagree about in the church, and which disagreements often are imposed on one another as objective truth and reality to be uncritically accepted, 'or else...'. Although talk is about relationships and groups in which relationship and language between people shape realities, the focus to this point was mostly on 'individual' or 'unique' realities. So, what is actually happening? Is it humans (agents) who create these 'truths', 'rules', and so on, or is it the groups or entities which do the creating, maintaining and sustaining of meaning - social constructions? This has been the age-old debate in sociological circles. People are not mere psychological beings, but social beings in social contexts. The way is then paved for the following reflection on sociological social constructionist thought.

The church is a social structure made up of human beings, and it is clear, from the social constructionist perspective, that knowledge, power and truth are dynamically interacting in church systems, culminating in personal and communal constructs, dominant discourses and narratives. A sociological reflection on social constructionist thought follows in the next section to reflect on these dynamics from a sociological perspective.

\section{A sociological perspective}

Sociology, according to The American Sociological Association (2006), is:

...the study of social life, social change, and the social causes and consequences of human behaviour and ... investigates the structure of groups, organizations, and societies, and how people interact within these contexts. (n.p.)

Sociology has to do with humans in social groups and settings. According to Barkan (1997:4), human behaviour and attitudes are profoundly shaped by society. People develop patterns of social interaction and social relationships in social settings and social settings shape our identity, actions, behaviour and attitudes.

Sociology thus studies relationships in and between groups. These may be small social structures, such as a family, or larger ones, such as organisations and institutions. Social class, poverty, race, gender and religion are some of the social issues studied by sociologists. Power and conflict are relevant topics for the purposes of this investigation. People's behaviour, choices, and understanding of the behaviour of others are often determined by guidelines rooted in the past.
Sociology has critique and healthy scepticism at its core. Critical thinking, according to Appelbaum and Chambliss (1997), is:

... a willingness to ask any question, no matter how difficult; to be open to any answer that is supported by reason and evidence; and to confront one's own biases and prejudices openly when they get in the way. (p. 5)

Sociology explores issues which usually bring about major conflict and controversy (cf. Giddens 1987:2).

'Social construction', first termed by sociologists Berger and Luckmann in The social construction of reality (1966), deals with constructs or applications which are natural and obvious to those who accept, practise and impose them on their followers, but in reality are man-made inventions of a particular society, structure or culture in a dialectical process (cf. MacDonald 2004:10).

Berger and Luckmann's central thesis is then that the individual is a producer and the individual's social world is the product of their dialectical relationship (Berger \& Luckmann 1966:78; cf. MacDonald [1988] 2004:10). A structure may have its genesis in as few as two people who dynamically interact in what is to become a social system, such as the church which has its beginnings in Jesus and his few disciples (see MacDonald [1988] 2004:12). They shape concepts and rules mutually of and for each other's actions. These rules and concepts become set ways or habits in the form of reciprocal roles played by the people (actors) involved in relationship with one another. As soon as more people join the group these rules (and roles?) are conveyed from generation to generation and justified as the group's identity. Berger and Luckmann call this 'institutionalization' (Berger \& Luckmann 1966:78).

Institutionalization is the process of entrenching meaning in society. Beliefs, actions, knowledge about reality and what it is are firmly rooted in and shaped by the institutional fabrication of society. So-called 'reality', which in the church, for example, is seen as objective, and which takes the form of institutionalised roles, rules and concepts, is thus, according to this theory, human fabrication with the purpose of creating meaning in the church in a very specific context, such as culture, time in history and human needs at the time. This is seen as an ongoing, dynamic process which develops in levels, with a final level: the symbolic universe. Berger and Luckmann (1966) assert that:

... the symbolic universe is conceived of as the matrix of all socially objectivated and subjectively real meanings; the entire historic society and the entire biography of the individual are seen as events taking place within this universe. (p. 114; cf. MacDonald 2004:11)

The habitualised activities are reproductions (with very little effort) of actions that are followed with such regularity that they become patterned as solid and even unchangeable. When these patterns become part of shared social interactions, they become 'typified' by what Berger and Luckmann (1966:72) refer to as 'typification'. MacDonald (2004) observes regarding the church: 
If one follows Berger and Luckmann's definition of institutionalization, it must be admitted that institutionalization was a process that began among Jesus and his followers and continued with the construction of the church. (p. 12)

Berger and Luckmann (1966) further theorise:

It follows that the expanding institutional order develops a corresponding canopy of legitimations, stretching over it a protective cover of both cognitive and normative interpretation. These legitimations are learned by the new generation during the same process that socializes them into the institutional order. (p. 79)

As new generations thus get added to the social structure, the social structure (institutionalised typifications) needs to be passed on and justified. This process they call 'legitimation'.

Important for this investigation, MacDonald (2004:16) argues that Berger and Luckmann believe that, in the light of human fallibility of human socialization and also in the light of their argument that all human social phenomena are humanly constructed, no symbolic universe can be completely taken for granted. In the case of the church, this 'taken-forgrantedness' could provide further explanation for imposing 'truths' and norms, which are typified and legitimised on others, which may cause experiences of abuse.

Conscientization in the church and pastoral care ministry is needed. Berger and Luckmann's line of thought and explanation of how current actions, roles and activities become part of a 'symbolic universe' can stimulate thought and self-reflection on some (or all) of the 'shoulds', 'musts' and 'oughts' in the church. It may also explain why there is often silence around activities and behaviours which some experience as abuse. The justification may lie hidden in a symbolic universe with solidified (agreed upon) typifications and legitimations which were institutionalised over time from generation to generation. These may have become obsolete in postmodern times. It is therefore important to explore the relationship between different beliefs and the social realities in which they are rooted (MacDonald 2004:27). Berger and Luckmann's theory places strong emphasis on human action and the role of human actors in the processes of institutionalization, typification, legitimation and the creation of a symbolic universe (cf. Smith 1991:51). Anthony Giddens (1984) places stronger emphasis on the duality of structure and actor (agent) which may provide valuable insight into the shaping of humans by the structure as well, and, if this process is ignored and taken for granted, how it may contribute to conflict and harmful activities.

Anthony Giddens, in his work Constitution of society (1984), criticises Berger and Luckmann's approach to social constructionism as being too one-sided, placing too much emphasis on the human actor, neglecting the role the social structure plays. Giddens introduces what he terms duality of agent and structure in his structuration theory. Structuration theory sees socio-cultural systems and human agents as involved in a reflexive process - reflexivity (ibid:42-44). This simply means that continuity and change, the reproduction and development of social systems come about through the mutual contribution by both structure (society or group) and social action (by individuals). Societal structures shape human action and human activity shapes and re-shapes structural patterns.

Social constructions come about through repeated behaviours which are reified as structure. Freewill and determinism are therefore mutually responsible for shaping process and product. Structure is not separate and external to the individuals and the actions of those individuals who make up the structure. Patterns of social action are reproduced and reoccur, resulting in what we conceptualise as social structures, for example, the church.

By application then, according to Giddens, the church as social structure, as we see it, and as it continues to be the church, and also the changes that take place in it, both arbitrate the organisational actions and are also shaped by and through those actions, none of which precedes the other. Therefore, just as Gergen has contended from a psychological perspective, both Berger and Luckmann's and Giddens's sociological theories also give hope: humans can be active participants in bringing about change in our social structures.

When, according to Giddens, we apply this to the church, the church does not exist without human actions (agency), but it is made up and exists within each active participant and is made up of patterns of actions, behaviours, rules and so on, which are reified over time. Eventually, they are almost seen as separate objective entities, but they can only exist whilst active participating humans continue to reproduce these patterns of behaviours, rules and actions.

According to Giddens, humans are knowledgeable and have the ability to reflexively examine the social activity within the structure. 'Agency' refers to the power of humans to independently act upon and challenge the determined limitations of the social structure. Giddens (1984) argues:

Human social activities, like some self-reproducing items in nature, are recursive. That is to say, they are not brought into being by social actors but continually recreated by them via the very means whereby they express themselves as actors. In and through their activities agents reproduce the conditions that make these activities possible. (p. 2)

Structuration theory thus proposes three key facets, namely (1) structures (component systems of signification, control and legitimation), (2) human action (systems of communication, power and sanction) which is recursively linked by (3) modalities (interpretive schemes, rules, resources and norms). These modalities are accessed by human actors to recursively link structures and human action, reproducing and modifying systems of interaction, through component relations, following cyclic patterns.

These cyclic patterns involve the continuous attempt, involving three interrelated component systems, to establish meaning, order relations and demarcate behaviour patterns 
focusing on issues of signification (could we say meaningconstruction?), power and control and regulation (Giddens $1979,1984)$.

As far as signification or signs and communication are concerned, the social actors draw on the sources of shared or mutual knowledge to construct meaning. 'Shared meaning' is fundamental to the production and reproduction of the social interactions in the system. Each interaction is in turn shaped by the social interaction. The rules and codes of interpretive schemes are used by the social agents to make sense of new or changed situations (Cohen 1990:27).

Giddens (1979:100) further asserts that, as far as power and control are concerned, authoritative and allocative resources are used to create or generate control over other social actors or people and objects. Power is reciprocally situated in the individual as well as in the organisation or institution, '... but structures of control have transformative capacity over organisational actors through the consistent allocation of resources' (ibid:93).

Whilst there is a fundamental relationship between actors and power, control is not absolute, and alternative action is known as the dialectic of control (Giddens 1979:6). According to Giddens, control is never absolute in any system, and systems must engage in debate about degrees of application, limits of discretion and adaptation to new social circumstances, changing the 'rules'. As far as legitimization and sanctions go, again social agents '... draw upon rules and normative practices that govern legitimate social practice ...', according to each specific unique context:

The values and goals deeply imbedded in structure are articulated as rights and obligations. Rules define normative practice and mediate appropriate performance through sanctions and inducements. Legitimate social performance is often articulated and sustained through orchestrated socialization, or the rituals, rites and ceremonies of tradition. Broadcasting preferred behaviours and enculturing acceptable practice. (ibid:n.p.)

Cohen (1990:27-28) refers to asymmetrical relationships within and between sanctions and resources, showing that a similar reinforcing interrelatedness which exists between the three key constructing social practices, namely construction of meaning, control and regulation, also exists asymmetrically between sanctions and resources.

Resources are mobilised involving practices which are both normative and follow existing meaning constructions. Sewell (1992) explains:

Rules not only sanction conduct, but themselves also constitute meaning. Structures are sustained through the mutual interaction of resources and rules and without this recursive regeneration they would over time disintegrate and cease to exist. (p. 13)

\section{A theological perspective}

One of Gergen's (2009:5-13) 'backbone' assumptions of social constructionism is that belief systems (especially dominant narratives, discourses, language) should be reflected on, revisited, tested and challenged. A narrative, according to Dreyer (2003a:317), is the history of a group in story form, but also an indicator of the meaning attached to events by the group, for instance, the church. Jesus is the key actor in what Heiler (1961:283-286) termed, amongst other types, salvation or revelatory type myth. Dreyer (2003a:317) refers to the Jesus story as foundational narrative: the story in which the Christian faith and the church are rooted.

Don Browning (in MacDonald [1988] 2004:12) sees the way that Jesus and his followers initially interacted as active initiating and participating in the social construction of the church through the process of Berger and Luckmann's institutionalization. Jesus therefore is a key actor in the foundational narrative of the church and Christian faith. Dreyer (2003a:320) argues that the religious personality models behaviour and thought on the godly activities of ancestors, such as prophets, apostles and other charismatic individuals. Faith communities, thus, position themselves regarding future vision and mission, closely linked to narratives rooted in latent foundational myths (ibid).

This positioning with regard to the future should not be described without taking into account the narratives and mythological character of the faith community in question (Dreyer 2003a:320). McGrath (1990:35) describes the history of Jesus of Nazareth as '... the precipitating or generative event of Christian doctrine.' Behind the Christian faith community lies the foundational narrative, which is the narrative of Jesus. This is the reason for including a discussion of Jesus, firstly, because Jesus is generally seen as the modeller of behaviour and thought in the Christian church; secondly because Jesus so strongly challenged the religious of his time (Grenz 1997:106-109); and finally, I include Jesus, because of my inference that, although Jesus disagreed strongly with the teachings of his times, he returned to the foundational narrative at the root of God's activities: the covenant promise of the Old Testament (Grenz 1997:110).

According to La Sor, Hubbard and Bush (1982:1), in addition to reserving the right for himself to be the true interpreter of the Scriptures, Jesus recognised the latter's full authority as well as its binding nature for the followers of God (cf. Grenz 1997:106). Sanders (1975:62) describes Jesus as a better interpreter of the Scriptures than his contemporaries (cf. Burridge 2007:172). Jesus further saw the Scriptures as fully inspired by God and the foundation for his (often unheard of, unexpected, frightening, alien) teachings (Burridge 2007:170).

In the Jesus narrative the Old Testament as we know it was 'Scripture' or 'the Scriptures', as they were generally referred to, used by him and his disciples (La Sor et al. 1982:1). In the gospel of John, for example, Jesus is said to have challenged the current understanding of the Scriptures and he assigned new and/or different meaning to it. In another example, in Acts 10:35, Peter is reported as having gained a different, new understanding of the Scriptures. They recognised that, although the Scriptures were inspired by God, humans interpret and give meaning to it. No evidence of conflict 
over inspiration and authority of the Scriptures (ibid), but rather over interpretations. Jesus reserved the right to be the only true interpreter, and swords were crossed about interpretations of Scripture but not over its authority and/or inspiration. Jesus followed the Jewish traditions, practices and acknowledged their experiences with regard to reliance on the Scriptures and application, but differed on interpretation (see Jn 5:39; cf. the gospels and his discussions with regard to his sonship) (La Sor et al. 1982:1).

Church constitutions often allow for freedom of interpretation. I assume and accept that they are probably talking about peripheral issues, and not the core, fundamentally agreed upon issues (truths?) of our faith. The problem is that these constitutions are usually only applied and applicable as far as is agreed upon by those in power, if and when it suits them. Jesus sharply disagreed, according to La Sor et al. (1982:2), on two points:

- Legalism: Similarly to the Old Testament prophets, Jesus also reacted strongly against the emptiness of much of Jewish legalism '... in which routine and ritual had become a worthless substitute for purity of heart, integrity, and social concern (e.g. Mark 7:1-13; Matt 9:13; 12:7; which quotes Hos 6:6).' Käsemann (1970:40) contends that Jesus '... broke through the piety and theology of his contemporaries, and brought God's promise and love in place of the Mosaic law, his own endowment with the Spirit in place of casuistry, and grace in place of good works.'

- Central theme: Jesus also reacted against the central theme, insisting that he is the central theme and fulfilment of the Scriptures (Law, Old Testament) (cf. Jn 5:39).

This resulted in a reshaping of attitudes towards him and the Scriptures (see Lk 24:44), but also in sharp conflicts with '...the Jewish officialdom' (La Sor et al. 1982:2). How did he respond to the first disagreement above, that is, legalism and empty tradition? Firstly, in Matthew 5-7, Jesus reinterpreted the law in the Sermon on the Mount. Secondly, he renounced prevalent Jewish interpretations of the law. Thirdly, he reemphasised love, forgiveness, and inward piety. Fourthly, Jesus followed a dynamic approach (as opposed to the static approach of Jewish contemporaries) (La Sor et al. 1982:2), viewing the Scriptures as an '... inspired, authoritative record of God's activity in history, an activity which presses toward its denouement in his coming kingdom.' The Scriptures, approached from Jesus' interpretation and insights, become alive and a dynamic guidance to life and Christianity (Jn 5:39; 6:63). They are not an index or list of fixed (reified) principles which serve to regulate religious structure and agency (La Sor et al. 1982:2). ${ }^{1}$ Fifthly, he brought fresh import to some major prophetic themes '... which were neglected by many Jews in their magnification of the letter of the law' (La Sor et al. 1982:2). Sixthly, by the above, he revolutionised Old Testament interpretation, '.. by drawing together various strands of teaching and braiding them into a single cord in himself' (La Sor et al. 1982:2). Finally, he paved the way for his followers, for example, Matthew, who meticulously tried to show the 1.See the discussions of Berger and Luckman and Giddens above. connections of Old Testament prophecy and Christ's life. He often repeated the words 'to fulfil what was spoken' (see Mt 1:22; 2:15, 17, 23; 4:14; 12:17; 13:35; 21:4; 27:9). The gospel writers were open to reinterpretation, reconstruction and a rethinking of old 'truths'. However, their search for links, comparisons, and connections did not mean, and actually show a resistance to, a discarding of traditions, Scripture, or anything else. One senses an eagerness to find fresh connections and reconstructions of what was valuable to them with 'the new', which in this case was Christ and Christ's interpretation. La Sor et al. (1982) summarise:

He was the great prophet like Moses who taught the new law from the mountain, the peerless priest who made the whole temple system obsolete (cf. Matt. 12:6; John 2:13-15); the wise king, the 'greater than Solomon' (Matt. 12:42); David's son and Lord, rightful heir to Israel's throne (Mark 12:35-37; 15:2); the triumphant son of man (Dan 7:13ff.; Mark 13:26); and the suffering servant (Isa. 53; Mark 10:45). The great themes of prophetic expectation found their consummation in him' (italics mine to illustrate La Sor et al.'s description of what, in the context and scope of this work, can be described as a typical social constructionist activity, that is, dialoguing with, deconstructing and reconstruction of old systems and ideas). (p. 2)

In the times after Jesus' departure, and in the New Testament church, the Scriptures, as reinterpreted by Christ himself, were the foundation of teaching, preaching and the new way of doing faith (Christianity) (La Sor et al. 1982:1; cf. Scripture references above). Could Jesus then, in the light of the discussion above, be seen and described as a social constructionist? From the above, I understand that he:

- demonstrated that what was believed to be absolute truth, was often the product of human interpretations

- showed that meaning was given by humans to the Scriptures which was not as God initially intended, so they constructed their own realities (in relationship as they were taught, and as it was passed on from generation to generation)

- deconstructed such constructions, by challenging current beliefs, interpretations and practices. Language was used by the Jews to describe the 'realities' of who the Messiah would be and what his functions and activities would look like, and also to describe what the followers of God should make of the Scriptures, and how they should practise their ways

- reconstructed the current constructions of what the Scriptures were all about. As described above, he showed how he was the centre and fulfilment of the prophecies, narratives, law and practices described in the Scriptures a total reconstruction of the Jewish faith and religion

- showed that their beliefs were rooted in the culture, history and practices of their time and not necessarily in the truth as revealed by God. It was very natural and fitting in their times to expect a king who would conquer and bring the people of Israel to a place and position of eternal peace and salvation in the light of Old Testament history and narrative

- showed how knowledge and power are connected. Those who held the dominant discourses were those who were in power positions. 
In addition to Jesus, a reflection on Paul follows in the next section as another biblical figure who can be described from a social constructionist perspective. Paul is seen in the Pauline narrative as an expert on the Scriptures, to the point of killing those who dared to challenge or think differently about them. Paul's narrative is a total deconstruction and reconstruction of dominant discourses treated as absolute truth, after an encounter with Jesus which left him physically blind. Paul's narrative further explains how he came to spend his life in deconstructing and reconstructing the Scriptures as previously understood to include the Gentiles as the people of God. Paul, throughout the New Testament, insists on the freedom in Christ, freedom from rules and the law and the imposing of 'old' Jewish ways and traditions on those who received Christ (Von Campenhausen 1969:46).

'As a Jew and a rabbi, Saul of Tarsus knew the Old Testament well; as a Christian and an apostle, Paul found the familiar text pregnant with fresh meaning', contend La Sor et al. (1982:3; italics mine). Paul seems to have come to a place where he was challenged (by Jesus himself) to open himself and everything that was familiar to him to the possibility that he was all along misunderstanding - or misinterpreting - the 'familiar text' that he 'knew well' as a Jew and rabbi. One can say that Jesus, in the Bible narrative, challenges Paul to reflect on his beliefs, reality and the consequential behaviour.

Regarding Paul's leadership and relationship with the churches, Von Campenhausen (1969:46) argues that Paul is a man of the highest authority, but refuses to develop this in the 'straightforward and obvious way by building up a sacral relationship of spiritual control and subordination' and that he rejects in no uncertain terms any right or desire to construct such form of authority and leadership (cf. MacDonald [1988] 2004:52).

Social constructionism assumes a strong relationship between power and knowledge. As Jew and rabbi Paul could be described as a man in a powerful position. Yet, he had to come to terms with and recognise (Gergen 2009:13) the above reality: that his 'reality' as far as the Scriptures and relevant knowledge were concerned had different meaning from that which was passed on, learned by and accepted as truth by him, all of which took place in relationship, that is, social context. He found a deeper meaning, value, and significance in the Scriptures as he knew them (La Sor et al. 1982:3; cf. Von Campenhausen 1969:46-47).

Important to note here is another social constructionist principle in La Sor et al. (1982):

The similarities between Christ's approach and Paul's are not accidental. Undoubtedly, Christ singled out relevant Old Testament passages and taught his disciples the principles by which they were to be interpreted. (p. 3; cf. Ellis 1957:113)

The social constructionist assumption is that meaning is assigned in relationship socially. So, the new meaning Paul found, was co-constructed in relationship with Christ mainly, but also with the other disciples. He did not discard the Old Testament principles and teaching altogether (Gergen 2009).
Paul depends heavily on the Old Testament in his teachings and in his letters to the different churches, which today form part of our New Testament as the epistles: Romans, 1 and 2 Corinthians and Galatians. He further draws heavily from the Old Testament in support of his argumentation regarding theological themes and doctrines, which can be seen as reconstructions of beliefs and ideas. He challenged the Jews, as well as the Gentiles strongly about their 'truths' held with regard to many issues (see especially Romans and Galatians) on beliefs regarding judgement, sin, circumcision, works, the law, and so forth.

Von Campenhausen (1969:46) also refers to Paul's insistence on Christ's leadership as well as Christ as central theme when he urges the church not to be slaves of men in 1 Corinthians 7:23. Paul's reconstructed meaning was so drastic and radical, that '... the Christ whose followers he had doggedly vowed to stamp out became for him the very heart of Old Testament revelation' (La Sor et al. 1982:3):

For Paul, Christ was not only a factor giving added meaning to the OT but the only means whereby the OT could be rightly understood; it was not merely that he saw Christ in the OT but that he viewed the whole scope of OT prophecy and history from the standpoint of the Messianic Age in which the OT stood open, fulfilled in Jesus Christ and in His new creation. (Ellis 1957:115)

Ellis talks here about 'rightly understood', which implicates the possibility of 'wrongly understood', of course. There is just no mention here of absolute truth, but rather an understanding of, or 'giving meaning to' what is already there (which indeed may be absolute, real or truth), but not free of understanding and a giving of meaning.

According to La Sor et al. (1982:3), the absolute truths or realities, as far as Paul's doctrines are concerned, are core issues, such as, amongst others: the fall of man and its consequences for man (Rm 5:12-21); the universality of sin (Rm 3:10-20); the obedience and sufferings of Christ (Rm 15:3); justification by faith (Rm 1:17; 4:1ff.; 10:5ff.), and final salvation of the Jews (Rm 11:26; cf. Ellis 1957:116):

The freedom with which Paul and other New Testament writers (especially Matthew) sometimes handled the Old Testament has been puzzling. At times they followed no known Greek or Hebrew textual tradition ... however, [their] interpretative glosses are usually not arbitrary or capricious but should be classed as quotation expositions which neither follow the text with slavish literalism nor alter its meaning with haphazard interpretation ... Paul paid close attention to historical setting and their grammatical structure ... to a meaning ... fits an overall interpretation of the Old Testament revelation. (La Sor et al. 1982:4-6)

Paul seems to have used the Scriptures in a way Ballard (2012:168) describes as 'theological reflection' with 'critical dialogue between the present reality and the tradition' at its core. Paul did not discard the 'truths' of Scripture, but reinterpreted them. His reinterpretations had Christ as centre (cf. Von Campenhausen 1969:46-48), bringing about a newfound freedom in faith which finds its expression in love (cf. Ballard \& Pritchard 2006:65-66, 82-87). Paul accepted the Scriptures as authoritative revelation (Brueggemann 2009:xx). 
This 'kind of wisdom', according to Ballard (2012:168), was termed by Paul Ricoeur as 'the second naïveté'. Hence, Paul did not just take tradition and the Scriptures as 'absolute truth' in a literal sense, but applied theological reflection as described above. New meaning was constructed which spoke of redemptive activity of God as opposed to 'lifeless enslaving laws' (La Sor et al. 1982:5; cf. Von Campenhausen 1969:46-47). This calls for a freedom from known ways and traditions. La Sor et al. (1982) continue:

The Old Testament context will not tell all one needs to know about the meaning of the passage, but unless one starts there, it becomes easy to twist the Scriptures to one's own purpose. (p. 6)

From the reflection on social constructionism above, it makes sense that confusion, fear and anxiety may be caused by assumptions regarding the non-existence of and challenging of objectivity, absolute truth to be found, studied and observed 'out there', and critical reflexivity about accepted givens in any setting. Paul demonstrated how current 'absolutes' could be approached and how they should be open to revisitation, challenge, deconstruction - thus, reflection (Gergen 2009:26) - and finally reconstruction for a fit with the present (Ballard 2012:168). Ballard (2012) describes this kind of reflection as follows:

Theological reflection as a deliberate process, therefore, aims to enable us to discern the wisdom of God in the scriptures for faithful living in the present ... The temptation is, however, to avoid the blood, sweat, and tears, to see the method as the substance, and to accept the short cut and easy response (p. 169)

From a theological perspective, for example, core beliefs form a critical part of the Christian faith and praxis. The easy way that Ballard describes above may mean that these beliefs, usually firmly supported by Scripture, are seen by many not only in very literal terms, but also as God's personally inspired final word. The interpretations thereof, however many, are often seen by those adhering to them, as in final (absolute) form and not to be questioned or challenged in any way (cf. Smith 1991:51). Gergen (2006:13) asserts that social constructionism's reflections on core traditions does not mean that they may be discarded, but that they can, and should, be reflected on, re-evaluated, reconsidered, and given new meaning, if necessary, negotiated and agreed upon. This kind of 'Bible wisdom', according to Ballard (2012:169; cf. Brueggeman 2009: xx), '... only comes from letting the Bible, in all its diversity and strangeness, become a companion on the way ...' and from allowing it, however perverse it may seem, to challenge our current assumptions - constructions. Brueggeman (2009:4) argues that in going about with the Scriptures we '... are re-describing the world, that is, construct $[i n g]$ it alternately.' The biggest fear in the church, I think, is that of relativism, leading to an 'everything goes because nothing can be absolutely true'-worldview. This is not what we see in Paul's interaction with the Scriptures and also not what is suggested in the reflection above. Rather, what is proposed is critical 'theological reflection' (Ballard 2012:168-169).

The reflection on Paul's example above, in a social constructionist sense, does not deny that tradition or 'reality out there' exists, but denies that it is ever free from human interpretation and meaning assigned in relationship, or from language as a medium to describe and create. In summary, the above discussion on Jesus and Paul shows:

- Freedom: There is a freedom from tradition and the known. Scripture is reinterpreted and new meaning assigned. The new meaning is free from literality, from historical context and from known ways of interpretation and application. There is also a freedom from lifeless law.

- Truth: Distinguishing between real and not so real 'absolute' truths: Jesus' absolute truths were that he was the central focus and meaning to be found in the Scriptures, based on the historical truths of humanity's need for salvation and God's plan of salvation. Similarly for Paul, all interpretation was in the light of these truths: challenging, deconstructing and reconstructing existing 'truth', 'meaning' and practices.

- Empowerment: Both Jesus and Paul were empowered by the supernatural Spirit of God to do what they were called to do. They never discarded the Scriptures, but under the guidance of the Spirit considered them free from human interpretation and construction.

The approaches and examples of Jesus and Paul above may be understood by some to simply imply and call for relativism in the Christian faith and community.

Anxiety, fear, anguish, pain, and similar painful and uncomfortable experiences are often experienced in the face of the perceived threat of existing constructions, concepts or constructs being nullified, challenged or changed. This anxiety is somewhat evident in arguments such as that of Müller (2011:80).

Practical theologian, Julian Müller (2011:77), refers to 'compelling knowledge', and, reasoning from a theological position, argues for a 'postfoundationalist' approach to knowledge. This, according to Müller, is a refusal to let go of 'compelling knowledge' (Müller 2011:77). Müller (2011:80) sees this approach as a protective measure against the relativistic tendencies often associated with social constructionism.

The kind of knowledge that mostly causes difficulties in church relationships seems to be the type which Chiari and Nuzzo (1996:163-184) refer to as a '... passive or receptive assimilation of a "noumenal" reality of "things in themselves," uncontaminated by human knowing.' This kind of knowledge is often concerned not with important core issues regarding the Christian faith, but with what was learned, passed on and interpreted without a critical approach such as that of Christ and Paul, for example (cf. Ballard 2012:168-169).

Even though Müller's description is indeed attractive and his intentions could be far removed from an insistence on a reality which is independent from human interpretation and conceptualization, surely even the concept 'compelling knowledge' has been, and will be, attributed various 
meanings by various people. 'Compelling knowledge' has been passed on from generation to generation as it was interpreted from the original writings which became what we know as the Scriptures today.

Language has been used to pass on 'compelling knowledge' and to describe (or give life or body or image) to it. 'Compelling knowledge' to some is not 'compelling knowledge' to others or it may be 'compelling', but with an altogether different meaning, association, or mood. This is, in light of social constructionist thought, because of different contexts, times in history, cultures, experiences and other influences to conceptualization. This stubborn clinging to and insistence on independent reality can lead to difficulty in relationships in the church, to abuse inflicted and experienced. 'Compelling knowledge', then, should be understood to exist, but not free from human experience, understanding, interpretation, that is, meaning making. The 'compelling knowledge' which we should hold on to and protect is the 'absolute truths' as mentioned above in the discussion about Paul and the truths on which he built his arguments.

In summary, much, if not all of what is treated and observed as 'absolute' and 'fact' is human-made and (should be) open to questioning, deconstruction and reconstruction, which is central to social constructionism, such as demonstrated by Jesus and Paul in their approach to the Scriptures.

Although I fully agree that objective reality exists, in light of the above it is important to keep in mind that this objective reality and truth are interpreted and tainted by our experience, context, interpretation and everything already mentioned above from a constructionist perspective, and are seen through these lenses. Therefore, it must be agreed at this point that no one can make a claim of possessing the absolute truth, because that absolute and 'objective' truth can never be 'objectively' (that is, free from interpretation, experience, relationship, and so on) defined; even the 'compelling knowledge and truth' spoken of above should regularly be revisited to make sure our understanding of it is as God intended. From a postmodern, social constructionist paradigm, it can be safely deduced that even some of the above can be misinterpreted or understood, which can cause difficulty in relationships: with self, with God and with others in the church. It is therefore relative to what meaning is assigned thereto.

Erickson refers to 'many experiential realities' (Erickson \& Rossi 1981:206; cf. Freedman \& Combs 1996:11). Erickson (ibid) also refers to this as 'plenty of alternatives in any situation ...'. So, my inference from the above is that the different 'realities' referred to above by Erickson, Freedman and Combs, and other postmodern thinkers refer to that which people perceive and their inner construction of the world as they make sense of it (cf. Brueggemann 2009:4).

This is often overlooked in church structures, which may lead to experiences of some as being abusive and hurtful, whilst their intention (and experience) is to do everything other than abuse and harm. At the same time some, such as Paul, may need an encounter and challenge to reflect on their current knowledge, interpretations and consequential (often very zealous) actions and behaviour.

Practical ministry, for example preaching, counselling and teaching, and 'doing' church, in the light of this could only benefit from theological reflection (Ballard 2012:168), which supposes openness to questioning - a questioning, and possibly deconstruction and reconstruction of existing beliefs, rituals, traditions and even interpretations. A simple understanding or attempt at understanding that humans actively construct, may in itself make a huge difference in the counsellor-counsellee dialogue, and in pastor-member, eldermember, leader-member and member-member interactivity. Whether this inner construction process happens biologically through the nervous system, purely through cognitive processes, just on a behavioural level, or in interactions and relations between systems, or all of these, is irrelevant. All of this, of course, takes place in a human's interaction with the environment, physically as well as socially, shared through the means of language and manifested in actions and behaviour.

The argument of this article is then for self-reflection, conscientization, acceptance of and integration of relativism in theology and theological theory and praxis. Note that this is not a radical relativism which assumes the non-existence of objective reality overall, but one which acknowledges that no reality is free from interpretation.

From the discussion so far it appears that social constructionism is the absolute ideal and final answer to all. Nightingale and Cromby (1999) challenge this idealistic approach to social constructionism.

Nightingale and Cromby (1999:2) criticise social constructionism as being 'wrong' in its very strong emphasis on language, which causes social constructionists to ignore the role of 'embodiment', 'materiality' and 'power'. Embodiment they view as the influence of:

'embodied factors (from missing limbs to cold sores) and ways in which the possibilities and constraints inherent in the material world always already shape and inform the social constructions we live through and with'. (p. 2)

Power refers to the 'power of institutions, governments and multinational corporations and the inequalities that arise from those structural features of society usually described under terms such as "capitalism" or "patriarchy" (Nightingale \& Cromby 1999:2). Nightingale and Cromby argue that we cannot reduce embodiment, materialism and power merely to language. They then include in their constructionism the 'real' (ibid:3), resonating well with my own stance on 'objective reality'. They refuse to make claims regarding the ontology, or 'lack thereof'. Nightingale and Cromby (ibid:3-6) acknowledge that social constructionism contains differences, nuances and incongruencies, but continue to summarise what is agreed upon by most: the principle assumptions. 
They include an outline of the disagreements surrounding them. What is mostly agreed upon is:

- The primacy of social processes: There is general consensus that our experiential world and the people we are, is 'first and foremost the product of social processes' (Nightingale \& Cromby 1999:3). Social institutions, such as the church, are made up of humans, who socially interact, organise and institutionalise in interaction with the structures they engage in. These humans, in turn, are shaped by relationships.

- Historical and cultural specificity: The relationships take place in dynamic cultures and history. What we know or think we know, the ways we find this out and what we count as evidence and proof varies along with different, ever-changing histories and cultures. This means that the 'subjectivities of the actual, living people that are constituted in and from those ways of speaking will vary, along with the cultures that produce and sustain them' (ibid:4). How 'women' and 'people' are perceived and understood 'fit[s] all too neatly with the demands of patriarchy and capitalism' and is '[the] determinants of social practices in which we make and find ourselves as the subjects of "patriarchy and capitalism", or alternatively as their opponents.' In the church setting these dominant discourses are imposed on others and cause relational disruption and pain.

- Knowledge and activity are intertwined: The questions we ask and the answers we come up with are rooted in our actions and activities and the purposes thereof at the time of questioning (ibid:3-4). Knowledge is shaped by what we are busy with. In a church, for example, questions and answers are shaped by the cultural and historical traditions - thus, humanly shaped activities.

- A critical stance: Very different from the positivist, empiricist tradition that assumes that 'facts' can be obtained by objective, neutral observation, social constructionism has a strong critical drive, growing from the assumptions of knowledge as relative and practice-born (ibid:4). The critical stance is what I argue for with regard to beliefs, practices and how we relate to this in the church. I argue for critical theological reflection as described by Ballard (2012:168-169).

There are not only agreements in each of these areas in social constructionism, but also disagreements, namely:

- The primacy of social processes: This point varies to some degree in respect of the extent to which it can be applied. Nightingale and Cromby (1999:4) refer to some (e.g. Edwards \& Potter 1992; Edwards, Ashmore \& Potter 1995) who 'seem to believe that when we talk about "reality" we can only be referring to the world we discursively construct, that "there is nothing beyond the text"' and others (e.g. Harré in Nightingale \& Cromby 1999:4) who 'accept that there is a real world beyond the text, but argue that what we can know of that real world is a sub-world or Umwelt restricted by the physiological, sensory apparatus of our species'. One of the points of departure of this article is also that there is a world 'out there'. However, no one can lay claim to absolute truth with regard to it, because everything is interpreted. I therefore agree with compelling truths as described by Müller (2011:77-80), but disagree with the view that we all have a universal understanding and interpretation of these truths.

- Historical and cultural specificity: Disagreements are between, on the one hand, those who emphasise the significant differences, 'even between neighbouring countries', or the important cultural shifts that can occur within one lifetime; hence, the argument that any and all aspects of existence may be subject to enormous variation. On the other hand, there are those who emphasise the sameness between and across cultures and argue that these should also be given some attention (Nightingale \& Cromby 1999:5). In the church, attention should be given to our differences in the face of our sameness. Although we may be from similar cultures and histories, there are individualities which may be explained by, for example, Kelly's (1955) personal construct theory as explained above, but also by individual and communal sense and meaning making processes.

- Knowledge and activity are intertwined: Whilst some social constructionists accept that 'there are basic aspects of the world preceding or transcending local human beliefs and activity', others, such as Burr (1995:5) - stating 'knowledge and social action go together', referred to in Nightingale and Cromby (1999:5) - believe that 'all knowledge is always local and particular.' Aspects of the Christian world that precede and transcend any human belief or activity are the core beliefs of our faith. These are the aspects referred to in what Ricoeur calls 'naïveté' (Brueggemann 2009:xx): the belief that the Scriptures are God-breathed and come with the authority of God. What needs to be understood, though, is that these Scriptures are interpreted and reflected upon by humans.

- A critical stance: Nightingale and Cromby describe two 'strands', both emphasising the social construction, 'and therefore malleable nature of our world', but with regards to the critical approach of constructionism. On the one hand are those who do not acknowledge any political activity in its relativism. On the other hand are those who 'hold that while social constructions are relative, they are not arbitrary, but emerge through social processes that are already shaped by influences such as power relationships and material resources'. They therefore 'differ in the extent to which they use this understanding as grounds for political (as opposed to philosophical or methodological) critique' (Nightingale and Cromby 1999:6):

A continuance to ignore or downplay embodiment and materiality may eventually create the conditions for the tide of knowledge and practice to simply sweep social constructionism away. The many psychologists who have recourse to notions of embodiment and materiality, both in their practice and in their everyday lives, are unlikely either to resign en masse or wholly to transform their approach simply because constructionism refuses to believe in them. It seems far more likely that social constructionism will simply make itself irrelevant and trivial, and so waste the valuable gains it has made. (Nightingale \& Cromby 1999:13) 
I believe in 'absolute realities and truths' which stand independently from language discourse, social processes, historical and experiential context, in agreement with what Nightingale and Cromby (1999:2-13) say above. But, at the same time I firmly believe and hold to this theorising about the social, individual, active, form-giving or shaping, transformative ability and character of humans, whether on a cognitive level, as Kelly explained in his social constructivist Psychological Personal Construct Theory (1955), or on a social relational level (Gergen 2009).

\section{Conclusion}

The conclusion reached in this article is what one can call an extremist-non-extremist approach to reality. On the extremist side of the continuum is the acknowledgement that no reality, irrespective of its true existence or otherwise, is free from human meaning-giving activity. On the non-extremist side is the acknowledgement that in our agreement, social relationship and social interaction we can come extremely close to an acceptable truth. Constructions taking the form of dominant, grand or abusive discourse need to be identified, challenged, deconstructed and reconstructed or replaced with more appropriate discourse in pastoral care and ministry.

\section{Acknowledgements Competing interests}

The authors declare that they have no financial or personal relationship(s) which may have inappropriately influenced them in writing this article.

\section{Authors' contributions}

This article represents a reworked version of aspects from the PhD dissertation of R.A.V. (University of Pretoria, April 2013), with Y.D. (University of Pretoria) as supervisor.

\section{References}

American Sociological Association (ASA), 2006, What is sociology?, viewed on 08 February 2012, from http://www.asanet.org/cs/root/topnav/sociologists/what is_sociology

Appelbaum, R.P. \& Chambliss, W.J., 1997, Sociology, Longman, Menlo Park, CA.

Ballard, P., 2012, 'The use of Scripture', in B.J. Miller-McLemore (ed.), The Wiley Blackwell companion to Practical Theology, pp. 163-172, Wiley-Blackwell, Oxford.

Ballard, P.H. \& Pritchard, J.L., 2006, Practical theology in action: Christian thinking in the service of church and society, SPCK Publishers, London.

Barkan, S.E., 1997, Criminology: A sociological understanding, Prentice Hall, Upper Saddle River, NJ.

Berger, P.L. \& Luckmann, T., 1966, The social construction of reality: A treatise in the sociology of knowledge, Doubleday, New York.

Berger, P.L. \& Luckmann, T., 1967, The social construction of reality: A treatise in the sociology of knowledge, Doubleday, New York.

Brueggemann, W., 2009, The prophetic imagination, Fortress Press, Philadelphia, PA. Bugental, J.F.T., 1976, The search for existential identity, Jossey-Bass, New Jersey, NJ.

Burr, V., 1995, An introduction to social constructionism, Routledge, London. http:// dx.doi.org/10.4324/9780203299968, PMCid:1511110

Burridge, R.A., 2007, Imitating Jesus: An inclusive approach to New Testament ethics, Eerdmans, Grand Rapids, MI.

Butler, L.H., 2012, 'Psychological theory', in B.J. McLemore (ed.), The Wiley-Blackwell companion to Practical Theology, pp. 102-111, Wiley-Blackwell, Oxford.

Chiari, G. \& Nuzzo, M.L., 1996, 'Psychological constructivisms: A metatheoretical differentiation', Journal of Constructivist Psychology 9, 163-184. http://dx.doi. org/10.1080/10720539608404663
Chiari, G. \& Nuzzo, M.L., 2004, 'Steering personal construct theory toward hermeneutic constructivism', in J.D. Raskin \& S.K. Bridges (eds.), Studies in meaning 2: Bridging the personal and social in constructivist psychology, pp. 51-65, Pace University Press, New York, NY.

Cohen, D., 1990, Being a man, Routledge, London.

Dreyer, Y., 2003a "n Teoretiese inleiding tot narratiewe hermeneutiek in die teologie', HTS Teologiese Studies/Theological Studies 59(2), 313-332. http://dx.doi. org/10.4102/hts.v59i2.661

Dreyer, Y., 2003b, 'Luister na die storie van die kerk', HTS Teologiese Studies/ Theological Studies 59(2), 333-352. http://dx.doi.org/10.4102/hts.v59i2.663

Edwards, D. \& Potter, J., 1992, Discursive psychology, Sage, London.

Edwards, D., Ashmore, M. \& Potter, J., 1995, 'Death and furniture: The rhetoric, politics and theology of bottom-line arguments against relativism', History of Human Sciences 8(2), 25-49. http://dx.doi.org/10.1177/095269519500800202

Ellis, E.E., 1957, Paul's use of the Old Testament, Eerdmans, Grand Rapids, MI.

Erickson, M.H. \& Rossi, E.L., 1981, Experiencing hypnosis, Irvington, New York, NY.

Fransella, F., 1996, George Kelly, Sage, London.

Freedman, J. \& Combs, G., 1996, Narrative therapy: The social construction of preferred realities, Norton \& Co., New York, NY.

Gergen, K.J., 1985, 'The social constructionist movement in psychology', American Psychologist 40, 266-275. http://dx.doi.org/10.1037/0003-066X.40.3.266

Gergen, K.J., 1988, 'Feminist critique of science and the challenge of social epistemology', in M. Gergen (ed.), Feminist thought and the structure of knowledge, pp. 27-44, Sage, London.

Gergen, K.J., 1990, 'Towards a postmodern psychology', in S. Kvale (ed.), Psychology and postmodernism, pp. 17-30, Sage, London.

Gergen, K.J., 2001, Social construction in context, Sage, London.

Gergen, K.J., 2006, Realities and relationships: Soundings in social construction, Harvard University Press, Cambridge, MA.

Gergen, K.J., 2009, An invitation to social construction, 2nd edn., Sage, London.

Giddens, A., 1979, Problems in social theory: Action, structure and contradiction in social analysis, University of California Press, Berkeley, CA. PMid:108341, PMCid:2231874

Giddens, A., 1984, The constitution of society: Outline of the theory of structuration, University of California Press, Berkeley, CA.

Giddens, A., 1987, Social theory and modern sociology, Stanford University Press, Stanford, CA.

Goldenberg, H. \& Goldenberg, I., 2008, Family therapy: An overview, Thomson Brooks/Cole, Belmont, CA.

Grenz, S.J., 1997, The moral quest: Foundations of Christian ethics, Intervarsity Press, Downers Grove, IL.

Heiler, F., 1961, Erscheinungsformen und Wesen der Religion, Kohlhammer, Stuttgart. (Die Religion der Menschheit, Bd. 1.)

Hoffman, M., 1990, UK arms control in the 1990s, Manchester University Press, New York.

Käsemann, E., 1970, Jesus means freedom, transl. F. Clark, Fortress, Philadelphia.

Kelly, G.A., 1955, The psychology of personal constructs, Norton \& Co., New York.

La Sor, W.S., Hubbard, D.A. \& Bush, F.W. (eds.), 1982, Old Testament survey: The message, form and background of the Old Testament, Eerdmans, Grand Rapids.

MacDonald, M.Y., [1988] 2004, The Pauline churches, Cambridge University Press, Cambridge, New York, NY.

Maddi, S.R., 1996, Personality theories: A comparative analysis, Dorsey Press, Menominee, $\mathrm{Ml}$.

McGrath, A.E., 1990, The genesis of doctrine: A study in the foundation of doctrina criticism, Eerdmans, Grand Rapids, MI.

Müller, J.C., 2011, 'Postfoundational practical theology for a time of transition', HTS Teologiese Studies/Theological Studies 67(1), Art. \#837, 5 pages. http://dx.doi. org/10.4102/hts.v67i1.837

Neimeyer, R.A. \& Bridges, S.K., 2004, 'Constructivism', in The Encyclopaedia of Personal Construct Psychology, viewed 12 February 2012, from from http://www. pcp-net.org/encyclopaedia/constructivism.html

Nightingale, D.J. \& Cromby, J., 1999, Social constructionist theory: A critical analysis of theory and practice, Open University Press, Maidenhead.

Sanders, J.T., 1975, Ethics in the New Testament, Fortress Press, Minneapolis, MN.

Sewell, W.H., 1992, 'A theory of structure: Duality, agency, and transformation', The American Journal of Sociology 98(1), 1-29. http://dx.doi.org/10.1086/229967

Smith, J.A. (ed.), 2008, Qualitative psychology: A practical guide to research method, 2nd edn., Sage, London.

Smith, W.C., 1991, The meaning and end of religion, Fortress Press, Minneapolis, MN.

Sternberg, R.J., 2001, Psychology in search of the human mind, 3rd edn., Harcourt College, New York, NY.

Von Campenhausen, H., 1969, Ecclesiastical authority and spiritual power in the church of the first three centuries, Stanford University Press, Stanford, CA. PMid:5822783

The Encyclopaedia of Personal Construct Psychology, n.d., Pc-theory, viewed on 17 November 2010, from http://www.pcp-net.org/encyclopaedia/pc-theory.html 